\title{
The Effect of Servant Leadership on Teacher Alienation: The Mediating Role of Supportive School Culture
}

\section{Research Article}

\section{Mahmut POLATCAN ${ }^{1}$}

${ }^{1}$ Karabuk University, Faculty of Letters, Department of Educational Sciences, Turkey, ORCID: 0000-0002-5181-0316

To cite this article: Polatcan, M. (2020). The Effect of Servant Leadership on Teacher Alienation: The Mediating Role of Supportive School Culture, International Online Journal of Educational Sciences, 12(3), 57-67.



(C) 2020 IOJES. All rights reserved

Keywords:

Servant leadership, teacher alienation, supportive school culture.

\section{Introduction}

Qualified teachers play a crucial role in student achievement and motivation. Studies, therefore, focus on improving the quality of teachers to improve that of education (Skaalvik \& Skaalvik, 2016). Recent research shows that teachers' performance, motivation and job satisfaction are negatively affected by numerous factors such as burnout (Skaalvik \& Skaalvik, 2017; Van Maele \& Van Houtte, 2015), stress (Prilleltensky, Neff, \& Bessell, 2016; Skaalvik \& Skaalvik, 2016), cynicism (Akin, 2015; Gökyer \& Türkoğlu, 2018), and intention to quit the job (Tiplic, Brandmo, \& Elstad, 2015). Alienation is a reason for teachers' failure to perform their duties well (Eryllmaz \& Burgaz, 2011). Some indicators of alienation are reduced organizational commitment, failure of organizational integration, poor relationships with colleagues, distance from work, and finding tasks

\footnotetext{
${ }^{1}$ Corresponding author's address: Karabuk University, Faculty of Letters, Turkey

Telephone:0(370) $4186689-6689$

e-mail: mahmutpolatcan78@gmail.com

DOI: https://doi.org/10.15345/iojes.2020.03.005
} 
meaningless (Sidorkin, 2004). Research addresses school alienation from the perspectives of weakness, meaninglessness, normlessness, social isolation, and self-alienation (Dash \& Vohra, 2018; Erdem, 2014).

Research shows that bureaucratic school structure, intensive education program, undemocratic school management, unilateral decision-making, and excessive workload lead to teacher alienation (Hascher \& Hadjar, 2018; Sidorkin, 2004; Vavrus, 1989). However, teachers are dissatisfied with their jobs and encounter conflicts when school principals control their professional activities and when they are not provided with the opportunity to plan their careers (Çağlar, 2012). Accountability-oriented teaching and learning processes also increase teachers' stress and anxiety (Valli \& Buese, 2007), which causes them to distance themselves from their professional responsibilities and find teaching activities meaningless and teaching monotonous in general (Sidorkin, 2004). Alienation weakens teacher cooperation and participation in school activities (Kulka, Kahle, \& Klingel, 1982). It is, therefore, necessary to focus on teacher alienation to improve educational quality and teaching efficiency.

Failure of schools to meet teacher needs, bureaucratic management, unilateral decision-making, and conflicts in employee communication lead to teacher alienation (Sidorkin, 2004). School principals' leadership behaviors play a key role in solving those issues. The increased importance of ethics and human-oriented management in developing organizations has led to different leadership behaviors (Black, 2010; Hoy \& Miskel, 2010). Twenty-first century school principals are expected to be visionary, creative, well-informed, and inspiring educational leaders who live up to their principles (Black, 2010). School principals who can delegate, make work meaningful, and promote employee participation and interaction help reduce the negative effects of alienation (Duyan \& Van Dierendonck, 2014; Tekingündüz, Kurtuldu \& Eğilmez, 2016). Research emphasizes that leadership requires influence, followers and objectives (Lunenburg \& Ornstein, 2013; Northouse, 2018; Yukl, 1989). Beliefs and expectations that principals affect school performance are related to servant leadership style (Cerit, 2009; Messner, Newcom Belcher, \& Fridell, 2009). Employees' needs and demands should be taken into account to discourage negative organizational behaviors. Changing organizational conditions have led to the emergence of servant leadership, which is a human-centered and ethical-management style inspired by employees' ideas (Van Dierendonck, 2011). Servant leaders focus unconditionally on employees' problems and support them (Black, 2010; Lantu, 2015). Greenleaf (1977) argues that servant leadership can only be possible by unconditional and conscious aspiration to serve. In this context, servant leaders should be able to listen to, heal and persuade others, and have high awareness and foresight (Spears, 2010). This can positively affect the motivation and performance of teachers who adopt school culture (Black, 2010; Hoy \& Miskel, 2010).

The central administrative structure of the Turkish education system has brought with it the mentality of bureaucratic management. The strict rules and procedures in the Turkish education system prevent teachers from focusing on their main tasks (Cemaloğlu, 2005; Turhan \& Karabatak, 2015; Korkmaz, 2005). Teachers who do not participate in decision-making processes and do not have support for professional development might face alienation. However, teachers are expected to make efforts to improve themselves and to produce innovative and creative ideas in educational settings governed by servant management mentality (Türkmenoğlu \& Bülbül, 2015; Çimen \& Karadağ, 2019). There are, however, very few studies addressing the relationship between servant leadership and teacher alienation (Ünsal, 2018) and supportive school culture (Kahveci \& Aypay, 2013; Yalçın \& Karadağ, 2013). Therefore, the aim of this study was to address school principals' servant leadership behavior and supportive school culture in order to reduce the effect of teacher alienation due to their negative feelings and attitudes towards school. 


\section{Conceptual Framework}

\section{Servant Leadership and Supportive School Culture}

Servant leaders are good listeners who dedicate themselves to organizations to solve organizational problems and to meet organizational needs. However, servant leaders should support their employees, and provide them with autonomy and safe and secure working conditions to allow them to develop themselves (Greenleaf, 1977). Servant leadership philosophy, which focuses on solving problems and meeting needs, require organizational compliance, positive organizational change, and maximum employee contribution for a successful organization (Barbuto \& Wheeler, 2006; Sendjaya \& Sarros, 2002; Stone, Russell, \& Patterson, 2004; Spears, 2010). School principals with servant leadership behaviors are expected to communicate effectively with teachers and find solutions to their problems (Kahveci \& Aypay, 2013; Reno, Friend, Caruthers \& Smith, 2017). In this context, servant leaders have an impact on supportive school culture of values, experiences and traditions. School culture is needed for school development and empowerment (Sergiovanni, 2001). The employees of schools with a rich culture have effective interaction and high confidence (Terosky \& Reitano, 2016; Terzi, 2005; Kahveci \& Aypay, 2013; Şişman, 2002). In supportive school culture, the relationship between principals and teachers is based on cooperation, honesty and open communication (Kosar \& Calik, 2011; Sezgin, 2010). It can, therefore, be argued that servant leaders play a key role in developing supportive school culture. The first hypothesis of this study was as follows:

H1: Servant leadership positively predicts supportive school culture.

\section{Servant Leadership and Teacher Alienation}

Teacher behavior depends on school principals' management approach. Job dissatisfaction, unmet needs, and ineffective communication between colleagues cause alienation (Simsek, Balay \& Simsek, 2006). Education becomes duller and more unappealing when teachers are uninterested in activities and find teaching processes meaningless (Eryllmaz \& Burgaz, 2011). Teacher alienation may negatively affect the relationship between teachers and their attitudes towards their duties (Kurtulmuş \& Yiğit, 2016). Servant leadership promotes the collaboration between employees and encourages them for emotional and professional development. Emotional interaction results in strong and positive relationships between leaders and their employees (Al-Mahdy, Al-Harthi \& Salah al-Din, 2016). Common traditions, beliefs, ideals, attitudes and assumptions play a key role in reducing teacher alienation (Bursalığlu, 2011). Genuine managers who take into account employee interests and needs, and have empathic communication skills, and a sense of justice and consistent behavior can help reduce teacher alienation (Palta, 2018). Principals with servant leadership behaviors can reduce teacher alienation. The second hypothesis of the study was, therefore, as follows:

H2: Servant leadership negatively predicts teacher alienation.

\section{Mediating Role of Supportive School Culture}

Not only school community members but also school principals play a crucial role in the development of school culture (Hoy \& Miskel, 2010). Servant leadership is based on serving others (Sendjaya \& Sarros, 2002). Servant leaders should, therefore, take their followers' needs and interests into consideration and help them solve their problems (Yalçın \& Karadağ, 2013). Otherwise, it leads to poor supportive school culture, resulting in breakdowns in communication and trust among school members, and an increase in conflicts (Özdemir, 2006). Inadequate organizational supportive school culture and collaboration negatively affect employee performance (Tanrıverdi \& Kıllç, 2016). The community of schools with supportive school culture have confidence in teachers and meet their educational needs to improve their performance (Lee \& Louis, 2019). However, favorable working environments provided by school principals enable teachers to develop positive 
attitudes towards school (Uzun, 2018). Servant school principals and supportive school culture in their schools allow teachers to communicate more effectively with each other and enjoy working (Demirtaş, Özer, Demirbilek \& Bal1, 2017), which might help them manage feelings of meaninglessness, loneliness and powerlessness, and feel less alienated. The third hypothesis of the study was, therefore, as follows:

H3: Servant leadership negatively predicts teacher alienation, and supportive school culture plays a mediating role in it.

\section{Method}

\section{Research Model}

A correlational survey model was used in this study, which addressed the relationship between servant leadership, alienation and supportive school culture based on primary and secondary school teachers' views.

\section{Sample}

The study population consisted of primary and secondary school teachers in Şişli/Istanbul in 2018. The reason for choosing primary and secondary school teachers in the research is that these schools have a similar culture. The population of the study consisted of 1680 teachers. According to the sampling calculation method, the number of teachers who need to participate in the research is 322. The number of returned surveys is 244 . The study sample consisted of 244 voluntary participants recruited convenience sampling method. This sampling method is used when the researcher is unable to use the other sampling method. Thus, the researcher chooses a situation that is close and easy to access. Participants, $64.3 \%$ were women, $62 \%$ were secondary school teachers, $23 \%$ had 1-5 years of work experience, $34 \%$ had 6-10 years of work experience, and $42 \%$ had more than 10 years of work experience.

\section{Instruments}

The Servant Leadership Assessment Instrument (SLAI) was developed by Dennis and Bocarnea (2005) and adapted to Turkish by Aslan and Özata (2011). It consists of 14 items and 5 subscales (love, empowerment, vision, altruism and trust). The scale items are scored on a 5-point Likert scale (" 1 = Strongly Disagree," to " 5 = Strongly Agree"). Some of the scale items are: "My leader entrusts me to make decisions" and "The level of trust my leader places in me increases my commitment to the organization." An Exploratory Factor Analysis (AFA) was performed for construct validity. The Kaiser-Meyer-Olkin (KMO) was 0.87, for which the Bartlett's test of sphericity was significant $(\chi 2=2455.19, p<.05)$. AFA revealed one factor explaining $54.47 \%$ of the variance. According to the reliability analysis, SLAI item-total correlation coefficients ranged from .58 to .76 ., and the Cronbach's Alpha was .93.

The Teachers' Work Alienation Scale (TWAS) developed by Elma (2003) consists of 38 five-point Likert type ("1: Never" to "5: Always") items and four subscales (powerlessness, meaninglessness, isolation, school alienation). Some of the scale items are "I feel lonely at school" and "I find teaching boring." In this study, the Kaiser-Meyer-Olkin (KMO) was 0.97 , for which the Bartlett's test of sphericity was significant $(\chi 2=6504.52$, $p<.05)$. In AFA, five items had low factor loadings and therefore was excluded from analysis. AFA revealed one factor explaining $45.21 \%$ of the variance. According to the reliability analysis, TWAS item-total correlation coefficients ranged from .42 to .77., and the Cronbach's Alpha was .96.

The school culture subscale of the Organizational Culture Scale developed by Terzi (2005) was used to measure supportive school culture, which was the mediating variable in this study. The subscale consists of eight items scored on a 5-point Likert scale ("1: Never" to "5: Always"). Some of the scale items are "People love each other in this school" and "People care about each other in this school." An AFA was performed for construct validity. The Kaiser-Meyer-Olkin (KMO) was 0.89, for which the Bartlett's test of sphericity was significant $(\chi 2=1195.32, p<.05)$. AFA revealed one factor explaining $62.38 \%$ of the variance. According to the 
reliability analysis, the corrected item-total correlation coefficients ranged from .55 to .80 ., and the Cronbach's Alpha was .91.

\section{Data Analysis}

Data were analyzed using Hayes Process Macro for the Statistical Package for Social Sciences (SPSS) at a significance level of $\mathrm{p}<.05$. Before analysis, outliers and missing data were checked to make sure that data did not deviate significantly from normal distribution. Mahalanobis distances for multivariate outlier detection were used for outlier analysis. Outliers with high significant values $(p<.05)$ were excluded from analysis (Gürbüz, 2019). In Process Macro, mediation effects are tested using Bootstrapping data according to confidence intervals, and mediation tests yield more valid and reliable results (Fritz \& MacKinnon, 2007). Mean and standard deviation values were used to determine servant leadership, supportive school culture and alienation levels. Correlation analysis was used to determine the relationship between the variables. Regression analysis was used to determine the predictive power and mediation of the variables. For regression analysis, data should be normally distributed, and correlation between variables should not be too high. In this study, skewness and kurtosis ranged from .72 to -.48. Distribution is near-normal if skewness and kurtosis both ranges from -1 to 1 (Tabachnick \& Fidell, 2007). In accordance with the second assumption of regression analysis, the correlation between the variables was between -.51 and -.52. Multicollinearity, variance inflation factor (VIF) and tolerance values were examined. VIF values were smaller than 10 while the condition index values were smaller than 30 . These results showed that the data were suitable for regression analysis.

\section{Results}

Table 1 shows the mean and standard deviation values, and the correlations between the variables.

Table 1. Mean, standard deviation and correlations values

\begin{tabular}{llcccc}
\hline Variables & $\bar{X}$ & Sd. & 1 & 2 & 3 \\
\hline 1-Servant Leadership & 3.86 & .80 & - & $.52^{* *}$ & $-.52^{* *}$ \\
2-Supportive School Culture & 3.69 & .81 & & - & $-.51^{* *}$ \\
3-Teacher Alienation & 1.88 & .72 & & -
\end{tabular}

**: Correlations is significant at the .01 level.

Participants thought that servant leadership $(\bar{X}=3.86)$ and supportive school culture $(\bar{X}=3.69)$ were high in primary and secondary schools. Servant leadership was moderately positively correlated with supportive school culture $(r=.52, p<.01)$ and was moderately negatively correlated with alienation $(r=-.52$, $p<.01)$. Supportive school culture, on the other hand, was moderately negatively correlated with alienation $(r$ $=-.51, p<.01)$. In other words, the higher the servant leadership, the higher the supportive school culture whereas the higher the servant leadership and supportive school culture, the lower the alienation.

For mediation analysis, a bootstrapping approach by Preacher and Hayes (2004) was used to test the mediating effect of supportive school culture. The causal steps approach outlined by Baron and Kenny (1986) are commonly used for mediation analysis. However, failure to meet the normality assumption, which is a prerequisite for some analyses, reduces reliability. Therefore, confidence intervals are analyzed in Bootstrap, which is regarded as contemporary mediation analysis. The Bootstrap method is more reliable than Baron and Kenny's traditional method and Sobel test (Fritz \& MacKinnon, 2007; Gürbüz, 2019; Hayes, 2009; 2018). The $95 \%$ bootstrap confidence intervals from 5000 bootstrap replicates should not contain zero $(0)$. Therefore, the 5000 bootstrap sample replicates, which can better at determining indirect effects than conventional methods, was used together with the 95\% symmetric confidence interval and 95\% bias-corrected and accelerated (BCa) bootstrap interval (Preacher and Hayes, 2008). Resulting bootstrapping values can be used to control distributional problems. 
Table 2. Total, direct and indirect effects on prediction of teacher alienation

\begin{tabular}{|c|c|c|c|c|c|c|c|}
\hline \multirow{3}{*}{ Effects } & \multirow{3}{*}{$b$} & \multirow{3}{*}{ S.E. } & \multirow{3}{*}{$\mathbf{t}$} & \multicolumn{4}{|c|}{$\% 95$ Confidence } \\
\hline & & & & \multirow[t]{2}{*}{$p$} & \multicolumn{2}{|c|}{ Interval } & \multirow[t]{2}{*}{$\mathbf{R}^{2}$} \\
\hline & & & & & LCI & UCI & \\
\hline Servant Leadership $\rightarrow$ Supportive School Culture & .52 & .05 & 9.51 & .00 & .419 & .638 & .27 \\
\hline Supportive School Culture $\rightarrow$ Teacher Alienation & -.28 & .05 & -5.35 & .00 & -.393 & -.182 & .35 \\
\hline Servant Leadership $\rightarrow$ Teacher Alienation & -.31 & .05 & -9.53 & .00 & -.422 & -.208 & \\
\hline Servant Leadership $\rightarrow$ Supportive School Culture & -.15 & .03 & - & - & -.236 & -.084 & - \\
\hline \multicolumn{8}{|l|}{$\rightarrow$ Teacher Alienation } \\
\hline Total Effect & -.46 & .04 & -9.53 & .00 & -.564 & -.371 & - \\
\hline
\end{tabular}

b: Non-standardized Coefficients, S.E.: Standard Error, LCI-UCI (Lower Confidence Interval-Upper Confidence Interval)

Bootstrap-based regression analysis was performed to determine what kind of role supportive school culture played in the effect of school principals' servant leadership behaviors on teacher alienation. Servant leadership had a significant and positive effect on supportive school culture $(b=.52,95 \%$ CI $[.419, .638], \mathrm{t}=$ $9.51, p<.01)$. The $p$-value was less than .01 and the confidence interval did not contain zero, indicating that the unstandardized beta coefficient was significant. Servant leadership explained about $27 \%\left(R^{2}=.27\right)$ of the variance in supportive school culture. Secondly, supportive school culture had a significant and negative effect on alienation $(b=-.28,95 \%$ CI $[-.393,-.182], \mathrm{t}=-5.35, p<.01)$. Servant leadership had a significant and negative effect on alienation $(b=-.31,95 \%$ CI $[-.422,-.108], \mathrm{t}=-9.53, p<.01)$. Supportive school culture and servant leadership explained about $35 \%(\mathrm{R} 2=.35)$ of the variance in alienation. Thirdly, servant leadership had a significant and negative effect on alienation in the model in which supportive school culture was not included as a mediating variable $(b=.46,95 \%$ CI $[-.564,-.371], \mathrm{t}=-9.53, p<.01)$. Lastly, servant leadership had an effect on teacher alienation. Supportive school culture had a continuous, albeit decreasing, effect on the relationship between servant leadership and teacher alienation, suggesting that it played a partially mediating role $(b=-$ $15,95 \%$ CI $[-2.236, .084])$. The indirect effect value $(b=-.15)$ suggested that the higher the servant leadership, the higher the supportive school culture while the higher the supportive school culture, the lower the teacher alienation. The bias-corrected and accelerated (BCa) bootstrap interval did not contain zero. The partially and fully standardized mediation effect sizes were $\mathrm{K}^{2}=-.21$ and $\mathrm{K}^{2}=-.17$, respectively. The effect size is low if $\mathrm{K}^{2}$ is close to .01, the effect size is moderate if $\mathrm{K}^{2}$ is close to .09 , and the effect size is high if $\mathrm{K}^{2}$ is close to .25 . This shows that the model had a mediation effect close to high.

\section{Discussion}

This study investigated the relationship between teacher alienation, school principals' servant leadership behaviors and supportive school culture. Alienation as well as burnout, stress, anxiety and cynicism reduce teachers' performance. This study examined the effect of school principals' servant leadership behaviors and supportive school culture on teacher alienation. According to participants, primary schools had moderate supportive school culture and had principals with moderate servant leadership behaviors, suggesting that schools have adequate servant leadership (Gül \& Türkmen, 2016) and supportive school culture (Sezgin, 2010). Schools with supportive school culture enjoy good communication, cooperation, trust and altruism. The result also pointed to low levels of teacher alienation, which has been reported by other studies as well (Ayık \& Ataş-Akdemir, 2016; Korkmaz \& Çevik, 2018; Şimşek, Balay, \& Şimşek, 2012). Low teacher alienation means effective teachers and efficient teaching processes (Yıldız, Akgün \& Yıldız, 2013). These results indicate that primary and secondary school principals have good behaviors and that teachers enjoy supportive school culture and have low negative attitudes towards their schools and profession.

The results showed that school principals' servant leadership behaviors were positively correlated with supportive school culture, indicating that the higher the servant leadership, the higher the supportive school 
culture. This has also been reported by other studies (Herndon, 2007; Hill, 2007; Kahveci \& Aypay, 2013; Yalçın \& Karadağ, 2013). Zhang, Lin and Fong (2012) argue that servant leadership contributes to the achievement of common goals and to the development of teachers. Zamperlin (2012) states that servant leaders who value and empathize with teachers increase trust and interaction among school community members. For servant leaders, the needs of others take precedence over their own interests (Yalçın \& Karadağ, 2013) because servant leaders do not sit at the top of a hierarchical structure. Therefore, servant school principals adopt a solutionoriented management approach and communicate with teachers effectively, meet their needs and involve them in decision-making processes (Kahveci \& Aypay, 2013), thus, creating a rich school culture and motivating teachers to perform to the best of their abilities to achieve common school objectives.

Principals' servant leadership behaviors and supportive school culture were negatively correlated with teacher alienation, suggesting that the higher the servant leadership and supportive school culture, the lower the teacher alienation. This result is consistent with the theoretical framework of the study (Şimşek et al., 2006; Eryılmaz \& Burgaz, 2011; Kurtulmuş \& Yiğit, 2016). Ünsal (2018) also found that school principals' leadership behaviors reduced teacher alienation. School principals who do not take teachers' professional experiences into consideration cannot motivate them to achieve common goals (Başaran, 1998). Servant principals who provide a supportive school culture encourage teachers to make suggestions for improving the school and promote their collaboration (Özdemir, 2006). On the other hand, lack of a supportive school culture hinders teachers' performance and professional development (Argon, 2014). Servant leaders are expected to be honest, modest, reliable and fair. Therefore, servant school principals can help teachers to suffer less from feelings of alienation such as meaninglessness, powerlessness and isolation.

\section{Conclusion}

The results show that servant leadership behaviors increase supportive school culture and reduce teacher alienation. School principals' servant leadership behaviors motivate teachers to perform to the best of their abilities to achieve common objectives. Fairness, honesty and trust, which are some of the servant behaviors of school principals, help teachers to develop positive perceptions of them. On the other hand, principals with an autocratic style of management prevent teachers from performing their duties well and affect their performance negatively. To avoid this, school principals should adopt servant leadership and take teachers' views into consideration in management processes. The limitation of the study is the fact that it was conducted in primary schools only in Istanbul to analyze the relationship between school principals' servant leadership, supportive school culture and alienation. It is, therefore, recommended that those variables be investigated in different types of schools and different educational levels. There are very few studies investigating the effect of principals' servant leadership behaviors on reducing negative organizational behaviors in schools. Future studies should address the effect of servant leadership behaviors on silence, cynicism, burnout, stress and conflict in school settings. The results also show that supportive school culture plays a partially mediating role in the relationship between school principals' servant leadership behaviors and teacher alienation. Therefore, future studies should also investigate such organizational variables as commitment, organizational citizenship, and psychological empowerment, which may have a mediating role in the relationship between servant leadership and alienation. 


\section{REFERENCES}

Akın, U. (2012). Okul yöneticilerinin seçimi ve yetiştirilmesi: Türkiye ve seçilmiş ülkelerden farklı uygulamalar, karşılaştırmalar. Bolu Abant İzet Baysal Üniversitesi Sosyal Bilimler Enstitüsü Dergisi, 12(2), $1-30$.

Akın, U. (2015). The relationship between organizational cynicism and trust in schools: A research on teachers. Education and Science, 40(181), 175-189. doi:10.15390/EB.2015.4721

Al-Mahdy, Y. F., Al-Harthi, A. S., \& Salah El-Din, N. S. (2016). Perceptions of school principals' servant leadership and their teachers' job satisfaction in Oman. Leadership and Policy in Schools, 15(4), 543-566. doi: 10.1080/15700763.2015.1047032

Argon, T. (2014). Supporting human resources in educational institutions: Teacher views on administrator support. Journal of Human Sciences, 11(2), 691-729. doi: 10.14687/ijhs.v11i2.2848

Aslan, Ş., \& Özata, M. (2011). Sağlık çalışanlarında hizmetkâr liderlik: Dennis-Winston ve Dennis-Bocernea hizmetkâr liderlik ölçeklerinin geçerlik ve güvenirlik araştırması. Journal of Management Economics, 18(1), 140-154.

Ayık, A., \& Ataş-Akdemir, Ö. (2016). Öğretmen adaylarının okul yaşam kalitesi ve okula yabancılaşma algıları arasındaki ilişki. Kuram ve Uygulamada Egitim Yönetimi Dergisi, 21(4), 429-452. doi:10.14527/kuey.2015.016

Barbuto, J. E., \& Wheeler, D. W. (2006). Scale development and construct clarification of servant leadership. Group E Organization Management, 31(3), 300-326. doi: 10.1177/1059601106287091

Baron, R. M., \& Kenny, D. A. (1986). The moderator-mediator variable distinction in social psychological research: Conceptual, strategic, and statistical considerations. Journal of Personality and Social Psychology, 51(6), 1173.

Başaran, İ.E. (1998) Yönetimde insan ilişkileri. Ankara: Aydan Web Tesisleri.

Black, G. L. (2010). Correlational analysis of servant leadership and school climate. Journal of Catholic Education, 13(4), 437-466. doi:10.15365/joce.1304032013

Bursalığlu, Z. (2011). Okul yönetiminde yeni yapı ve davranış. Ankara: Pegem Akademi

Cemaloğlu, N. (2005). Türkiye de okul yöneticisi yetiştirme ve istihdamı varolan durum, gelecekteki olası gelişmeler ve sorunlar. Gazi Üniversitesi Gazi Eğitim Fakültesi Dergisi, 25(2), 249-274.

Cerit, Y. (2009). The effects of servant leadership behaviours of school principals on teachers' job satisfaction. Educational Management Administration E Leadership, 37(5), 600-623. doi:10.1177/1741143209339650

Çağlar, Ç. (2012). Öğrenci yabancılaşma ölçeğinin (ÖYÖ) geliştirilmesi. Ĕ̆itim ve Bilim, 37(166), $195-205$.

Çimen, B., \& Karadağ, E. (2019). Ruhsal liderlik, örgüt kültürü, örgütsel sessizlik ve okulun akademik başarısı. Kuram ve Uygulamada Egitim Yönetimi Dergisi, 25(1), 1-50. doi: 10.14527/kuey.2019.001.

Dash, S. S., \& Vohra, N. (2018). The leadership of the school principal: Impact on teachers' job crafting, alienation and commitment. Management Research Review, 42(3), 352-369. doi:10.1108/MRR-11-2017-0384

Demirtaş, H., Özer, N., Demirbilek, N., \& Balı, O. (2017). Relationship between the perceived principal support, trust in principal and organizational commitment. International Online Journal of Educational Sciences, 9(4), 1075-1092. doi: 10.15345/iojes.2017.04.013

Dennis, R. S., \& Bocarnea, M. (2005). Development of the servant leadership assessment instrument. Leadership $\mathcal{E}$ Organization Development Journal, 26(8), 600-615. doi:10.1108/01437730510633692

Duyan, E., \& Van Dierendonck, D. (2014). Hizmetkar liderliği anlamak: Teoriden ampirik araştırmaya doğru. Sosyoloji Konferansları, 49, 1-32.

Elma, C. (2003). Ilköğretim okulu öğretmenlerinin işe yabancılaşması. (Yayımlanmamış doktora tezi). Ankara Üniversitesi Eğitim Bilimleri Enstitüsü, Ankara.

Erdem, M. (2014). The level of quality of work life to predict work alienation. Educational Sciences: Theory and Practice, 14(2), 534-544. doi:10.12738/estp.2014.2.2126 
Eryılmaz, A., \& Burgaz, B. (2011). Özel ve resmi lise öğretmenlerinin örgütsel yabancılaşma düzeyleri. Eğitim ve Bilim, 36(161), 271-286.

Fritz, M. S., \& MacKinnon, D. P. (2007). Required sample size to detect the mediated effect. Psychological Science, 18(3), 233-239. doi: 10.1111/j.1467-9280.2007.01882.x

Gökyer, N., \& Türkoğlu, İ. (2018). The relationship between high school teachers' organizational support perceptions and their organizational cynicism attitudes. Education \& Science, 43(196), 317-340.

Greenleaf, R. K. (1977). Servant Leadership: A Journey into the nature of legitimate power and greatness. New York, NY: Paulist Press.

Gül, İ., \& Türkmen, F. (2016). Examining the school administrators' servant leadership behaviors according to teachers perception Journal of Human Sciences, 13(3), 5515-5529. doi:10.14687/jhs.v13i3.4290

Gürbüz, S. (2019). Sosyal bilimlerde aracı, düzenleyici ve durumsal etki analizleri. Ankara: Seçkin Yayıncılık.

Hascher, T., \& Hadjar, A. (2018). School alienation - theoretical approaches and educational research. Educational Research, 60(2), 171-188. doi:10.1080/00131881.2018.1443021

Hayes, A. F. (2009). Beyond Baron and Kenny: Statistical mediation analysis in the new millennium. Communication Monographs, 76 (4): 408-420

Hayes, A. F. (2018). Introduction to mediation, moderation, and conditional process analysis: A regression-based approach (Second edition). New York: Guilford Press.

Herndon, B. C. (2007). An analysis of the relationships between servant leadership, school culture, and student achievement. (Unpublished doctoral dissertation). University of Missouri, Columbia.

Hill, J. R. (2007). Servant leadership characteristics of high school principals, organizational culture, and student performance: A correlational study. (Unpublished doctoral dissertation). University of North Dakota, North Dakota.

Hoy, W. K., \& Miskel, C. G. (2010). Eğitim yönetimi (Trans. Ed.: S. Turan). Ankara: Nobel.

Kahveci, H., \& Aypay, A. (2013). Hizmetkâr liderlik ve okul kültürü arasındaki ilişkinin ilköğretim okullarında incelenmesi. Eğitimde Politika Analizi, 2(1), 44-60.

Korkmaz, M. (2005). Okul yöneticilerinin yetiştirilmesi: sorunlar çözümler ve öneriler. Gazi Üniversitesi Gazi Ĕ̆itim Fakültesi Dergisi, 25(3), 237-252

Korkmaz, M., \& Çevik, M. S. (2018). Ortaöğretim kurumlarında örgüt kültürü ile yabancılaşma arasındaki ilişkinin incelenmesi. Kuram ve Uygulamada Egitim Yönetimi Dergisi, 23(4), 675-716. doi:10.14527/kuey.2017.021

Koşar, S., \& Çalık, T. (2011). Okul yöneticilerinin yönetimde gücü kullanma stilleri ile örgüt kültürü arasındaki ilişki. Kuram ve Uygulamada Eğitim Yönetimi, 4(4), 581-603.

Kulka, R. A., Kahle, L. R., \& Klingel, D. M. (1982). Aggression, deviance, and personality adaptation as antecedents and consequences of alienation and involvement in high school. Journal of Youth and Adolescence, 11(3), 261-279. doi:10.1007/BF01537471

Kurtulmuş, M., \& Yiğit, B. (2016). İşe yabancılaşmanın öğretmenlerin işten ayrılma niyetine etkisi. Mersin University Journal of the Faculty of Education, 12(3), 860-871. 60-871. doi:10.17860/mersinefd.282385

Lantu, D. C. (2015). Servant leadership and human capital management: Case study in Citibank Indonesia. Procedia-Social and Behavioral Sciences, 169, 303-311. doi: 10.1016/j.sbspro.2015.01.314

Lee, M., \& Louis, K. S. (2019). Mapping a strong school culture and linking it to sustainable school improvement. Teaching and Teacher Education, 81, 84-96. doi: 10.1016/j.tate.2019.02.001

Lunenburg, F. C., \& Ornstein, A. C. (2013). Eğitim yönetimi (Trans. Ed.: G. Arastaman) (6 ed.). Ankara: Nobel Akademik Yayıncilık.

Messner, P. E., Newcom Belcher, R., \& Fridell, M. (2009). Discriminate analysis gender public school principal servant leadership differences. Leadership \& Organization Development Journal, 30(8), 722-736. doi:10.1108/01437730911003894 
Northouse, P. G. (2018). Introduction to leadership: Concepts and practice (5 ed.). Thousand Oaks, California: Sage Publications.

Özdemir, A. (2006). Okul kültürünün oluşturulması ve çevreye tanıtılmasında okul müdürlerinden beklenen ve onlarda gözlenen davranışlar. Türk Eğitim Bilimleri Dergisi, 4(4), 411-436.

Palta, A. (2018). Öğretmenlerin işe yabancılaşma düzeyleri ve yöneticilerinin liderlik stillerinin incelenmesi. Ulakbilge Sosyal Bilimler Dergisi, 6(31), 1670-1679.

Preacher, K. J. \& Hayes, A. F. (2004). SPSS and SAS procedures for estimating indirect effects in simple mediation models. Behavior Research Methods, Instruments and Computers, 36 (4), 717-731

Preacher, K. J. \& Hayes, A. F. (2008). Contemporary approaches to assessing mediation in communication research. In A. F. Hayes, M. S. Slater \& L. B. Snyder (Eds.), The SAGE sourcebook of advanced data analysis methods for communication research (pp. 13-54). Thousand Oaks, CA: Sage Publications.

Prilleltensky, I., Neff, M., \& Bessell, A. (2016). Teacher stress: what it is, why it's important, how it can be alleviated. Theory Into Practice, 55(2), 104-111. doi:10.1080/00405841.2016.1148986

Reno, G. D., Friend, J., Caruthers, L., \& Smith, D. (2017). Who's getting targeted for behavioral interventions? Exploring the connections between school culture, positive behavior support, and elementary student achievement. The Journal of Negro Education, 86(4), 423-438. doi: 10.7709/jnegroeducation.86.4.0423

Sendjaya, S., \& Sarros, J. C. (2002). Servant leadership: Its origin, development, and application in organizations. Journal of Leadership \& Organizational Studies, 9(2), 57-64. doi: 10.1177/107179190200900205

Sergiovanni, T. J. (2001). The principalship: a reflective practice perspective, needham heights. MD: Allyn and Bacon.

Sezgin, F. (2010). Öğretmenlerin örgütsel bağlılığının bir yordayıcısı olarak okul kültürü. Eğitim ve Bilim, 35(156), 143-159.

Sidorkin, A. M. (2004). In the event of learning: alienation and participative thinking in education. Educational Theory, 54(3), 251-262. doi:10.1111/j.0013-2004.2004.00018.x

Skaalvik, E., \& Skaalvik, S. (2016). Teacher stress and teacher self-efficacy as predictors of engagement, emotional exhaustion, and motivation to leave the teaching profession. Creative Education, 7(13), 17851799. doi:10.4236/ce.2016.713182

Skaalvik, E., \& Skaalvik, S. (2017). Dimensions of teacher burnout: relations with potential stressors at school. Social Psychology of Education, 20(4), 775-790. doi:10.1007/s11218-017-9391-0

Spears, L. C. (2010). Character and servant leadership: Ten characteristics of effective, caring leaders. The Journal of Virtues \& Leadership, 1(1), 25-30.

Stone, A., Russell, R. F., \& Patterson, K. (2004). Transformational versus servant leadership: A difference in leader focus. Leadership \& Organization Development Journal, 25(4), 349-361. doi: 10.1108/01437730410538671

Şimşek, H., Balay, R., \& Şimşek, A. S. (2012). İlköğretim sınıf öğretmenlerinde mesleki yabancılaşma. Eğitim Bilimleri Araştırmaları Dergisi, 2(1), 53-72.

Şişman, M. (2002). Örgütler ve kültürler. Ankara: Pegem Akademi.

Tabachnick, B. G. \& Fidell, L. S. (2007). Using multivariate statistics. Boston, MA: Pearson.

Tanrıverdi, H., \& Kılıç, N. (2016). Algılanan örgütsel destek ve örgütsel yabancılaşma arasındaki ilişkinin incelenmesi. Hacettepe Üniversitesi, Sosyolojik Araştırmalar E-Dergisi, 1(1), 1-18.

Tekingündüz, S., Kurtuldu, A., \& Eğilmez, Ç. (2016). The analysis of the effects of social support, job alienation and job stress on labour performance. Journal of Human Sciences, 13(1), 683-694. doi:10.14687/ijhs.v13i1.3512

Terosky, A. L., \& Reitano, M. C. (2016). Putting followers first: The role of servant leadership in cases of urban, public school principals. Journal of School Leadership, 26(2), 192-222. doi: 10.1177/105268461602600201

Terzi, A. R. (2005). İlköğretim okullarında okul kültürü. Kuram ve Uygulamada Ĕ̆itim Yönetimi, 11, 423-442.

Tiplic, D., Brandmo, C., \& Elstad, E. (2015). Antecedents of Norwegian beginning teachers' turnover intentions. Cambridge Journal of Education, 45(4), 451-474. doi:10.1080/0305764X.2014.987642 
Turhan, M., \& Karabatak, S. (2015). Türkiye'de okul yöneticilerinin yetiştirilmesi ve yurtiçi alanyazında sunulan model önerilerinin incelenmesi. Turkish Journal of Educational Studies, 2(3), 79-107.

Türkmenoğlu, G., \& Bülbül, T. (2015). Okul yöneticilerinin göreve geliş biçimlerinin okul kültürüne yansımaları. Mersin Üniversitesi Ĕ̆itim Fakültesi Dergisi, 11(2), 527-549. doi: 10.17860/efd.26254

Uzun, T. (2018). Okullarda algılanan örgütsel adalet, yönetici desteği ve örgütsel özdeşleşme arasındaki ilişkiler. Trakya Üniversitesi Ĕ̆itim Fakültesi Dergisi, 8(4), 776-789. doi: 10.24315/trkefd.366093

Ünsal, Y. (2018). Ĕğitim örgütlerinde sergilenen hizmetkar liderlik rollerinin öğretmenlerin örgütsel yabancilaşmalarına etkisi. (Yüksek lisans tezi). Harran Üniversitesi Sosyal Bilimler Enstitüsü, Şanlıurfa.

Valli, L., \& Buese, D. (2007). The changing roles of teachers in an era of high-stakes accountability. American Educational Research Journal, 44(3), 519-558. doi:10.3102/0002831207306859

Van Dierendonck, D. (2011). Servant leadership: A review and synthesis. Journal of Management, 37(4), 12281261. doi: 10.1177/0149206310380462

Van Maele, D., \& Van Houtte, M. (2015). Trust in school: a pathway to inhibit teacher burnout? Journal of Educational Administration, 53(1), 93-115. doi:10.1108/JEA-02-2014-0018

Vavrus, M. (1989). Alienation as the conceptual foundation for incorporating teacher empowerment into the teacher education knowledge base. Paper presented at the Proceedings of the National Forum of the Association of Independent Liberal Arts Colleges for Teacher Education Indianapolis. https://files.eric.ed.gov/fulltext/ED344851.pdf

Yalçın, M., \& Karadağ, E. (2013). Hizmetkar liderlik ve okul kültürü: Bir yapısal eşitlik modellemesi. İnönü Üniversitesi Eğitim Fakültesi Dergisi, 14(2), 101-120.

Yıldız, K., Akgün, N., \& Yıldız, S. (2013). İşe yabancılaşma ile örgütsel sinizm arasındaki ilişki. The Journal of Academic Social Science Studies, 6(6), 1253-1284.

Yukl, G. (1989). Managerial leadership: A review of theory and research. Journal of Management, 15(2), $251-289$. doi:10.1177/014920638901500207

Zamperlin, F. U. (2012). The role of servant leadership in middle school culture. (Unpublished doctoral dissertation). Fordham University, New York.

Zhang, Y., Lin, T. and Fong F. S. (2012). Servant leadership: a preferred style of school leadership in Singapore. Chinese Management Studies, 6(2), 369-383. doi:10.1108/17506141211236794 